\title{
Phenotypic and Genotypic Characterization of Lactic Acid Bacteria Isolated from Artisanal Italian Goat Cheese
}

\author{
E. COLOMBO, L. FRANZETTI,* M. FRUSCA, AND M. SCARPELLINI
}

Dipartimento di Scienze e Tecnologie Alimentari e Microbiologiche sez, Microbiologia Agraria Alimentare Ecologica, Università degli Studi di Milano, Via Celoria, 201333 Milano, Italy

MS 09-373: Received 3 September 2009/Accepted 17 December 2009

\begin{abstract}
The lactic acid bacteria community in traditional goat cheese produced in three dairies in Valsesia (Piemonte, Italy) was studied at different steps of the manufacturing process. These cheeses were produced from raw milk without starter bacteria, and no protocol was followed during the manufacturing process. Three hundred thirty-two isolates were characterized and grouped by results of both morphophysiological tests and random amplification of polymorphic DNA plus PCR analysis. Bacteria were identified by partial sequencing of the $16 \mathrm{~S}$ rRNA gene. Lactococci were the dominant lactic acid bacteria in raw milk. Their initial numbers ranged from 5 to $7 \log \mathrm{CFU} \mathrm{ml}{ }^{-1}$. Their levels increased during manufacturing and decreased during ripening. The growth trend for enterococci was comparable to that of lactococci, although enterococci counts were lower. Lactococcus lactis subsp. cremoris, Lactococcus garviae, and Enterococcus faecalis were the most frequently isolated species during goat cheese manufacturing, whereas the highest numbers of Enterococcus (E. faecium, E. durans, E. gilvus, and E. casseliflavus) were isolated with the greatest frequency from ripened cheese samples. Occasionally, Leuconostoc mesenteroides, Leuconostoc lactis, and Lactobacillus paraplantarum also were isolated.
\end{abstract}

Italian dairy production offers a wide variety of products, many of which the European Community has recognized as Product Denomination Origin. However, a large number of unrecognized artisanal products are characterized by nonstandardized manufacturing processes and have strong links to a limited geographical region, but marketing of these products has been limited. This group of artisanal products includes those made from goat's milk. In northern Italy, goat cheese production is concentrated in the alpine area, and the products are made from raw milk using traditional techniques. The manufacturing process is not standardized and does not employ starter cultures. Sensory characteristics depend on several factors, including the particular traditional cheesemaking practice, the feed provided to the animals, and the composition and dynamics of the microbial communities that are naturally present in milk and in the environment (29). Goat cheeses that have not been appreciated because of their peculiar sensory characteristics are becoming more popular (17).

Nonstarter lactic acid bacteria (NSLAB) form a complex microbial community that can be used to modify physical and chemical properties of cheese, contributing to changes that occur during the manufacturing and ripening of cheese (19). The selective conditions that persist during manufacturing process create different ecological niches. NSLAB dominate the microflora of long-ripened cheese for most of its ripening time and likely contribute to cheese maturation $(13,15,27)$. The characteristics of a given

\footnotetext{
* Author for correspondence. Tel: 0250319160; Fax: 0250319167;

E-mail: laura.franzetti@unimi.it.
}

cheese will be influenced by the dynamics of the microbial population. In the absence of a standardized process, the product has unique and typical sensorial qualities but is also difficult to export.

Phenotypic, biochemical, and physiological tests have been used to identify the microbial community associated with cheeses; however, for many artisanal cheeses the microbial populations are difficult to control because of their complex dynamics and interactions (1). Knowledge of the structure and dynamics of the whole microbial community of cheese would promote better understanding of how cheese characteristics are affected by microbial growth and metabolism. The development of PCR-based molecular techniques for the identification of bacterial species offers new approaches for microbial taxonomic studies $(2,3,5,11,15,20,21,24-26)$.

The aim of this work was to study the changes in LAB populations of artisanal goat cheeses during ripening. Characterization of LAB isolates to the strain level would allow cheese producers to select those bacteria that could be used for the preparation of starter cultures as part of a standardized protocol to produce goat cheeses with desirable and typical sensory qualities.

\section{MATERIALS AND METHODS}

Cheese manufacturing and sampling. The artisanal cheeses were prepared according to traditional practices from mixed refrigerated evening and fresh morning milk. The temperature of the milk was adjusted to approximately $35^{\circ} \mathrm{C}$, at which time commercial liquid rennet $(0.1 \mathrm{ml} / 1,000 \mathrm{ml}$ of milk) was added without adding starter culture. The formation of curd took 45 to 
$60 \mathrm{~min}$. The curd was cut into large pieces, heated to $40^{\circ} \mathrm{C}$, and broken into pieces the size of corn kernels. These pieces were collected in perforated plastic baskets $(20 \mathrm{~cm}$ in diameter), dried in a warm area $\left(20\right.$ to $\left.25^{\circ} \mathrm{C}\right)$ for 6 to $8 \mathrm{~h}$, immersed in brine for $2 \mathrm{~h}$, and ripened at $10^{\circ} \mathrm{C}$ for 1 to 2 months.

The production process in three small dairies (A, B, and C) in Valsesia (Piemonte, Italy) was studied. Production was monitored in winter and spring when animals were collected in the stable and eating only silage. Samples obtained at three different times from each dairy were analyzed: milk, curd, curd after warming, curd before and after brining, cheese after 1 month of ripening, and finished cheese. All samples were immediately refrigerated at $4{ }^{\circ} \mathrm{C}$ and transported to the laboratory under refrigerated conditions not later than $3 \mathrm{~h}$ after collection.

Enumeration and isolation of LAB. Ten grams of each sample was aseptically weighed and homogenized with $90 \mathrm{ml}$ of sterile $2 \%(\mathrm{wt} / \mathrm{vol})$ sodium citrate solution in a Stomacher 400 Circulator (PBI International, Milan, Italy) at $230 \mathrm{rpm}$ for $2 \mathrm{~min}$. Serial decimal dilutions were prepared in tryptone salt $(8.5 \mathrm{~g}$ of $\mathrm{NaCl}, 1 \mathrm{~g}$ of tryptone, and 1,000 $\mathrm{ml}$ of distilled water), and the following analyses were performed. Mesophilic lactic acid cocci were enumerated on M17 agar (Fluka, Buchs SG, Switzerland) (28) incubated aerobically at $30^{\circ} \mathrm{C}$ for $48 \mathrm{~h}$. Total LAB were enumerated on de Man Rogosa Sharpe agar (MRS; Merck, Darmstadt, Germany) (10) incubated under anaerobic conditions (Gas Pack) at $30^{\circ} \mathrm{C}$ for $48 \mathrm{~h}$, and enterococci were enumerated on kanamycin esculin azide agar (KEA; VWR, Darmstadt, Germany) (4) at $37^{\circ} \mathrm{C}$ for $48 \mathrm{~h}$. All microbiological analyses were carried out in triplicate, and the results were expressed as the mean CFU per milliliter or gram.

Twenty to 30 colonies from each sample were randomly collected from M17, MRS, and KEA corresponding to the last dilution at which growth occurred. These colonies were purified through two subsequent subcultures on M17, MRS, and KEA and stored in $20 \%$ (vol/vol) glycerol in an appropriate liquid medium at $-20^{\circ} \mathrm{C}$.

Phenotypic characterization. The isolates were characterized by examining their cellular morphology with a phase contrast microscopy $(480 \times)$, by Gram staining, and by a catalase test. Isolates that were gram positive and catalase negative were tested for gas production from glucose, $\mathrm{NH}_{3}$ production from arginine, growth at 45 and $10^{\circ} \mathrm{C}$, and (for cocci only) the hydrolysis of esculin.

DNA extraction. Genomic DNA from LAB isolates was extracted from $100 \mu \mathrm{l}$ of an overnight culture diluted with $300 \mu \mathrm{l}$ of $1 \times$ TE buffer $\left(10 \mathrm{mM}\right.$ Tris- $\mathrm{HCl}$ and $1 \mathrm{mM} \mathrm{Na}_{2}$ EDTA, $\mathrm{pH} \mathrm{8.0)}$ as described by Mora et al. (22).

PCR amplification (RAPD and 16S rDNA). LAB isolates were identified by random amplification of polymorphic DNA (RAPD) and PCR with universal primers and by $16 \mathrm{~S}$ rDNA gene sequencing. The RAPD-PCR was carried out with the M13 primer (5'-GAG GGT GGC GGT TCT-3') (18). The reaction mix was as follows: $14.9 \mu \mathrm{l}$ of milli-Q water, $2.5 \mu \mathrm{l}$ of $10 \times$ buffer, $4.0 \mu \mathrm{l}$ of $25 \mathrm{mM} \mathrm{MgCl} 2,0.25 \mu \mathrm{l}$ of $10 \mathrm{mM}$ concentrations of the deoxynucleoside triphosphates (dNTPs), $1.25 \mu$ of $100 \%$ dimethyl sulfoxide, $1.0 \mu \mathrm{l}$ of a $100 \mu \mathrm{M}$ concentration of primer, $0.10 \mu \mathrm{l}$ of $5 \mathrm{U} / \mu \mathrm{l} \mathrm{Taq}$ polymerase, and $1 \mu \mathrm{l}$ of DNA. An amplification cycle consisting of denaturation at $94^{\circ} \mathrm{C}$ for $1 \mathrm{~min}$, annealing at $43^{\circ} \mathrm{C}$ for $40 \mathrm{~s}$, and extension at $72^{\circ} \mathrm{C}$ for $2 \mathrm{~min}$ was repeated 34 times. The cycles were preceded by initial denaturation at $94^{\circ} \mathrm{C}$ for 2 min and followed by final extension at $72{ }^{\circ} \mathrm{C}$ for $7 \mathrm{~min}$. After amplification, $9 \mu \mathrm{l}$ of product was electrophoresed on a $1.5 \%$ agarose gel (with $0.2 \mu \mathrm{g} / \mathrm{ml}$ ethidium bromide) in TAE (Tris-acetate-EDTA) buffer at $5 \mathrm{vol} / \mathrm{cm}$.

The 16S rDNA gene was amplified with primers $16 \mathrm{Sf}\left(5^{\prime}-\right.$ CTACGGCTACCTTGTTACGA-3') and 16Sr (5'-AGAGTTTGATCCTGGCTCAG-3'). The reaction mix was as follows: $17.25 \mu \mathrm{l}$ of milli-Q water, $2.5 \mu \mathrm{l}$ of $10 \times$ buffer, $2.5 \mu \mathrm{l}$ of $25 \mathrm{mM}$ $\mathrm{MgCl}_{2}, 0.5 \mu \mathrm{l}$ of $10 \mathrm{mM}$ concentrations of dNTPs, $1.0 \mu \mathrm{l}$ of each $100 \mu \mathrm{mol}$ primer, $0.25 \mu \mathrm{l}$ of $5 \mathrm{U} / \mu \mathrm{l} \mathrm{Taq}$ polymerase, and $1 \mu \mathrm{l}$ of DNA. An amplification cycle of denaturation at $94^{\circ} \mathrm{C}$ for $45 \mathrm{~s}$, annealing at $50^{\circ} \mathrm{C}$ for $45 \mathrm{~s}$, and extension at $72^{\circ} \mathrm{C}$ for $1 \mathrm{~min}$ was repeated four times. The steps of denaturation at $94^{\circ} \mathrm{C}$ for $45 \mathrm{~s}$, annealing at $55^{\circ} \mathrm{C}$ for $35 \mathrm{~s}$, and extension at $72^{\circ} \mathrm{C}$ for $1 \mathrm{~min}$ were repeated 34 times. The cycles were preceded by initial denaturation at $94^{\circ} \mathrm{C}$ for $2 \mathrm{~min}$ and followed by final extension at $72^{\circ} \mathrm{C}$ for $7 \mathrm{~min}$. After amplification, $9 \mu \mathrm{l}$ of product was electrophoresed on $1 \%$ agarose gel (with $0.2 \mu \mathrm{g} / \mathrm{ml}$ ethidium bromide) in TAE buffer at $5 \mathrm{vol} / \mathrm{cm}$. For all amplifications, a negative control containing all described reagents but no DNA was included. Amplifications were carried out in a Biometra T-Gradient thermal cycler.

Sequence analysis. The $16 \mathrm{~S}$ rDNA gene was partially sequenced in the laboratories of PRIMM Company (Milan, Italy). The sequence for each strain was developed with CHROMAS 2.13 (Technelysium Pty Ltd., North Sydney, Australia). The results were compared with the sequence in an online database (www. ncib.nlm.nih.gov).

\section{RESULTS}

The changes of microbial indices investigated in each dairy during manufacturing process are presented in Table 1. There were no significant differences in microbial levels, but there were differences between cheeses and dairies in how the microflora changed over time and in the distribution of microflora during the phases of manufacture. LAB populations primarily consisted of lactococci. In dairies $\mathrm{B}$ and $\mathrm{C}$, the level of lactococci significantly increased from milk to curd formation to the brining stage, where lactococci peaked at 10 and $9.4 \log \mathrm{CFU} / \mathrm{g}$, respectively. After brining, populations of lactococci slowly but continuously decreased during the ripening phase $(\mathrm{R})$. In dairy A, lactococci grew until the warming phase (W) but did not reach populations as high as those observed in dairies $\mathrm{B}$ and $\mathrm{C}$. In subsequent phases, lactococcal populations reached a plateau and remained stable until the end of storage.

The growth trend for enterococci was comparable to that of lactococci, although this trend was characterized by lower microbial counts. In dairies $\mathrm{A}$ and $\mathrm{B}$, initial enterococcal populations in milk were 3.3 and $3.1 \log \mathrm{CFU} / \mathrm{ml}$ (about $2 \log$ lower than lactococcal populations), respectively. Subsequently, enterococci continuously and regularly increased until the warming step, where they reached populations similar to those of lactococci. The population then stabilized until the end of storage. Different behavior was observed in dairy $\mathrm{C}$, where enterococci grew until the brine phase but then decreased to the initial level during ripening.

One hundred sixty isolates were collected from KEA medium. Biochemical investigations confirmed that all isolates belonged to the genus Enterococcus (i.e., obligately 
TABLE 1. Counts of lactic acid bacteria $(L A B)$ during manufacturing and ripening of artisanal goat cheese

Mean and SD of bacterial counts $(\log \mathrm{CFU} / \mathrm{ml} \text { or } \mathrm{g})^{b}$

\begin{tabular}{|c|c|c|c|c|c|c|c|c|c|c|c|c|c|c|c|c|c|c|}
\hline \multirow{2}{*}{$\begin{array}{l}\text { Production } \\
\text { step }^{a}\end{array}$} & \multicolumn{6}{|c|}{ Dairy A } & \multicolumn{6}{|c|}{ Dairy B } & \multicolumn{6}{|c|}{ Dairy C } \\
\hline & \multicolumn{2}{|c|}{ Total LAB } & \multicolumn{2}{|c|}{ Lactococci } & \multicolumn{2}{|c|}{ Enterococci } & \multicolumn{2}{|c|}{ Total LAB } & \multicolumn{2}{|c|}{ Lactococci } & \multicolumn{2}{|c|}{ Enterococci } & \multicolumn{2}{|c|}{ Total LAB } & \multicolumn{2}{|c|}{ Lactococci } & \multicolumn{2}{|c|}{ Enterococci } \\
\hline M & 5.8 & 1.1 & 5.7 & 0.3 & 3.3 & 0.1 & 5.7 & 0.4 & 5.8 & 0.6 & 3.1 & 0.3 & 5.5 & 0.2 & 6.5 & 0.5 & 2.7 & 0.2 \\
\hline $\mathrm{C}$ & 6.8 & 0.7 & 7.5 & 0.6 & 5.5 & 0.5 & 7.5 & 0.1 & 7.5 & 0.2 & 5.7 & 0.3 & 6.3 & 0.1 & 6.9 & 0.5 & 2.7 & 0.1 \\
\hline $\mathrm{R}$ & 8.8 & 0.8 & 9.1 & 0.5 & 7.7 & 0.3 & 9.4 & 0.1 & 7.5 & 0.0 & 6.6 & 0.8 & 8.7 & 0.5 & 8.5 & 0.0 & 6.8 & 0.1 \\
\hline $\mathrm{FC}$ & 8.3 & 0.3 & 8.6 & 0.3 & 7.8 & 1.4 & 8.8 & 0.5 & 9.4 & 0.1 & 6.8 & 0.6 & 8.5 & 0.3 & 7.9 & 0.9 & 3.3 & 0.2 \\
\hline
\end{tabular}

${ }^{a}$ M, milk; C, curd; W, curd after warming; AB, curd after brining; R, cheese after 1 month; FC, finish cheese.

${ }^{b}$ Values are the average of three manufacturing batches. Counts are expressed as log CFU per milliliter for milk and log CFU per gram for curd and cheese.

homofermentative, 2,3,4-triphenyltetrazolium chloride reducers, and esculin hydrolase positive). The isolates from M17 and MRS were differentiated on the basis of their morphology and fermentation activity: 8 isolates were facultative heterofermentative rods, 8 were heterofermentative cocci, and 156 were homofermentative cocci. Preliminary identification and microbial diversity investigation of all isolates was performed using the RAPD-PCR assay with the universal M13 primer. RAPD analysis was used to create different groupings. Two representatives from each group were identified by partial $16 \mathrm{~S}$ rDNA sequencing (Table 2). The analysis of RAPD-PCR profiles grouped Lactococcus garviae, Lactococcus lactis subsp. lactis, Enterococcus faecalis, Enterococcus durans, and Enterococcus faecium strains into three, two, two, two, and two biotypes, respectively. Different RAPD profiles were obtained for some strains (Table 2) probably because different ribotypes can be obtained from a single organism (9). The most biodiversity was observed for E. faecalis, in which biotype $\mathrm{g}$ had five different RAPD profiles corresponding to the same accession number in the database. Other important intraspecies biodiversity was observed for Enterococcus gilvus and Lactobacillus paraplantarum. The distribution of each species during processing is listed in Table 3.

In dairy A, we found only cocci, and the homofermentative form was dominant. In raw milk, L. lactis subsp. cremoris and L. garviae accounted for more than $50 \%$ of the LAB isolates; $E$. faecalis was a quantitatively minor component (35\% of the isolates). At the beginning of milk transformation, the number of enterococci gradually increased. The most important was E. faecalis followed by $E$. faecium. During ripening, E. faecalis decreased but remained the dominant microbial form on cheese $(53 \%$ of the isolates), followed by $L$. garviae and L. lactis subsp. cremoris that together represented more than $40 \%$ of the isolates. L. mesenteroides was isolated only from raw milk and in small numbers, so we cannot consider this microorganism typical of this product (Table 3).

In dairy $\mathrm{B}$, lactococci were dominant in raw milk and primarily represented by L. garviae (35\% of the isolates) and L. lactis subsp. cremoris (27\% of the isolates). In milk, three species of enterococci (E. faecalis, E. gilvus, and $E$. durans) together accounted for $36 \%$ of the isolates. $L$. mesenteroides was observed in small quantities in both milk (2\% of the isolates) and curd (4\% of the isolates). During the milk transformation process and ripening, $L$. garviae was the major component, except during the warming phase when Enterococcus $(20 \%$ E. faecalis and $70 \%$ E. durans) prevailed. Ripening favored the growth of lactococci, which became more numerous than enterococci. $L$. garviae and $L$. lactis subsp. cremoris were always found in finished cheese and represented more than $50 \%$ of the isolates (Table 3 ). $L$. lactis subsp. cremoris became a minority component even though it may have contributed to the sensory properties. In the first month of ripening, Lactobacillus paraplantarum and Leuconostoc lactis also were found.

In dairy $\mathrm{C}$, a greater variability in bacterial species was observed, especially in the final phases of the cheese-making process. Enterococcus species were almost absent in raw milk but were the dominant component during manufacturing and ripening, represented by E. faecalis, E. faecium, E. durans, E. gilvus, and E. casseliflavus. In the final product, enterococci represented more than $80 \%$ of the isolates: $E$. faecalis (20\%), E. faecium (24\%), E. durans (20\%), and E. gilvus (20\%). Lactococci (L. lactis subsp. cremoris, $8 \% ; \mathrm{L}$. garviae, $4 \%$ ) were in the minority. In this dairy, two species of the genus Leuconostoc were found: L. mesenteroides and L. lactis. During ripening, L. paraplantarum and Pediococcus pentosaceus also were detected (Table 3 ).

\section{DISCUSSION}

Information about microbial populations and their development in artisanal dairy products is important for understanding the particular characteristics of these populations. This information also can be used to define and standardize these dairy products and consequently boost their marketability outside the local region.

Each dairy in the present study represented a different environment with various resident bacteria. The natural LAB population consisted of homofermentative cocci such as lactococci and enterococci. The rod form was observed 
TABLE 2. Distribution of lactic acid bacterial isolates and biotypes as determined by RAPD-PCR and partial sequencing of 16S rDNA during manufacturing of goat milk cheese ${ }^{a}$

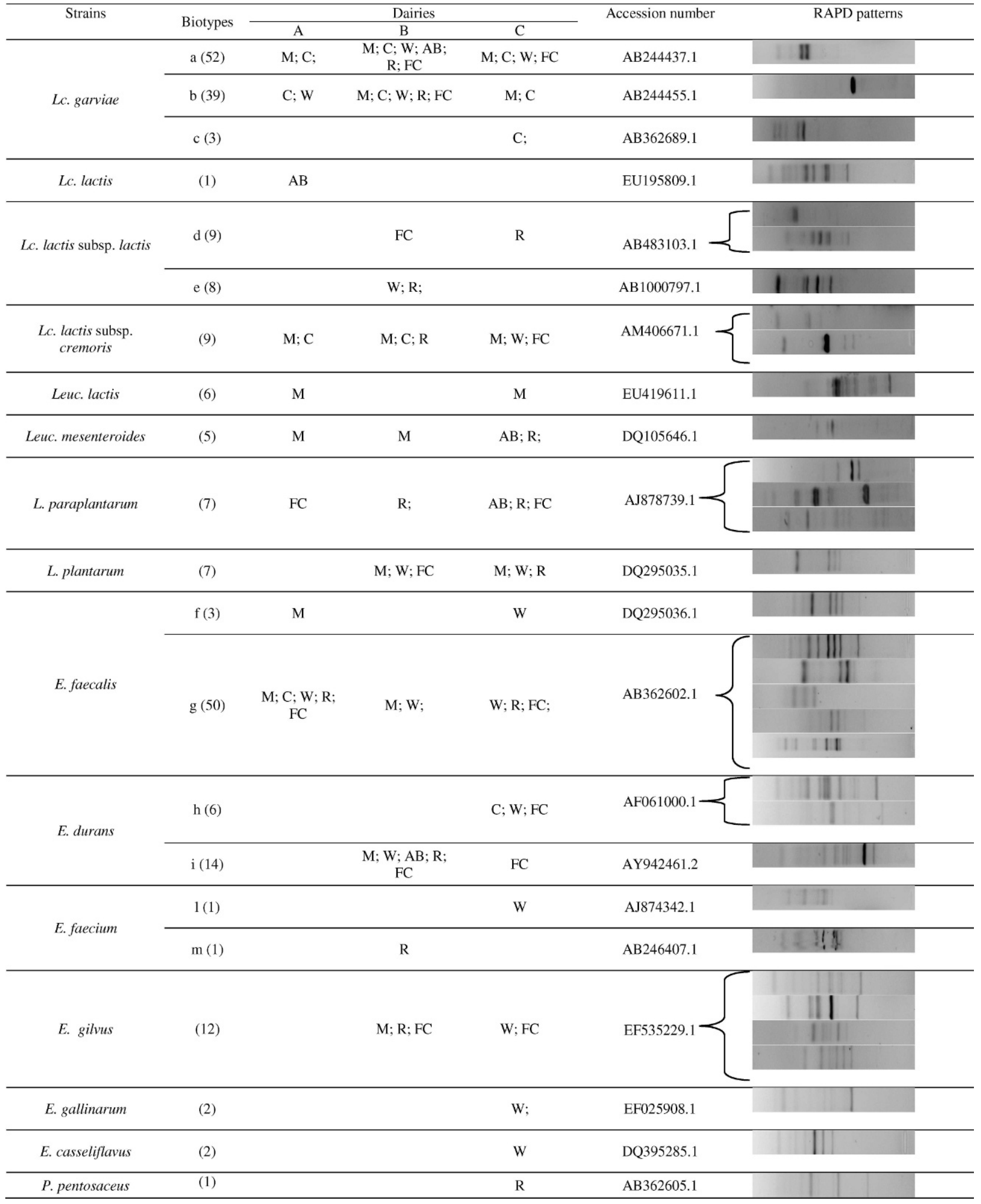

${ }^{a}$ M, milk; C, curd; W, curd after warming; AB, curd after brining; R, cheese after 1 month; FC, finish cheese. Marker is 1-kb Fermentas. The number of isolates is presented in parentheses.

only occasionally and at low numbers at the end of the manufacturing process. This finding is consistent with results obtained by others $(7,8)$. Lactococci play an important role in the initial milk coagulation process. Some strains of L. lactis subsp. cremoris are able to ferment citrate that is naturally present in milk and thus produce aromatic substances such as diacetyl, which confers the typical butter aroma $(7,8)$. 
TABLE 3. Distribution of lactic acid bacteria during manufacturing of goat cheese

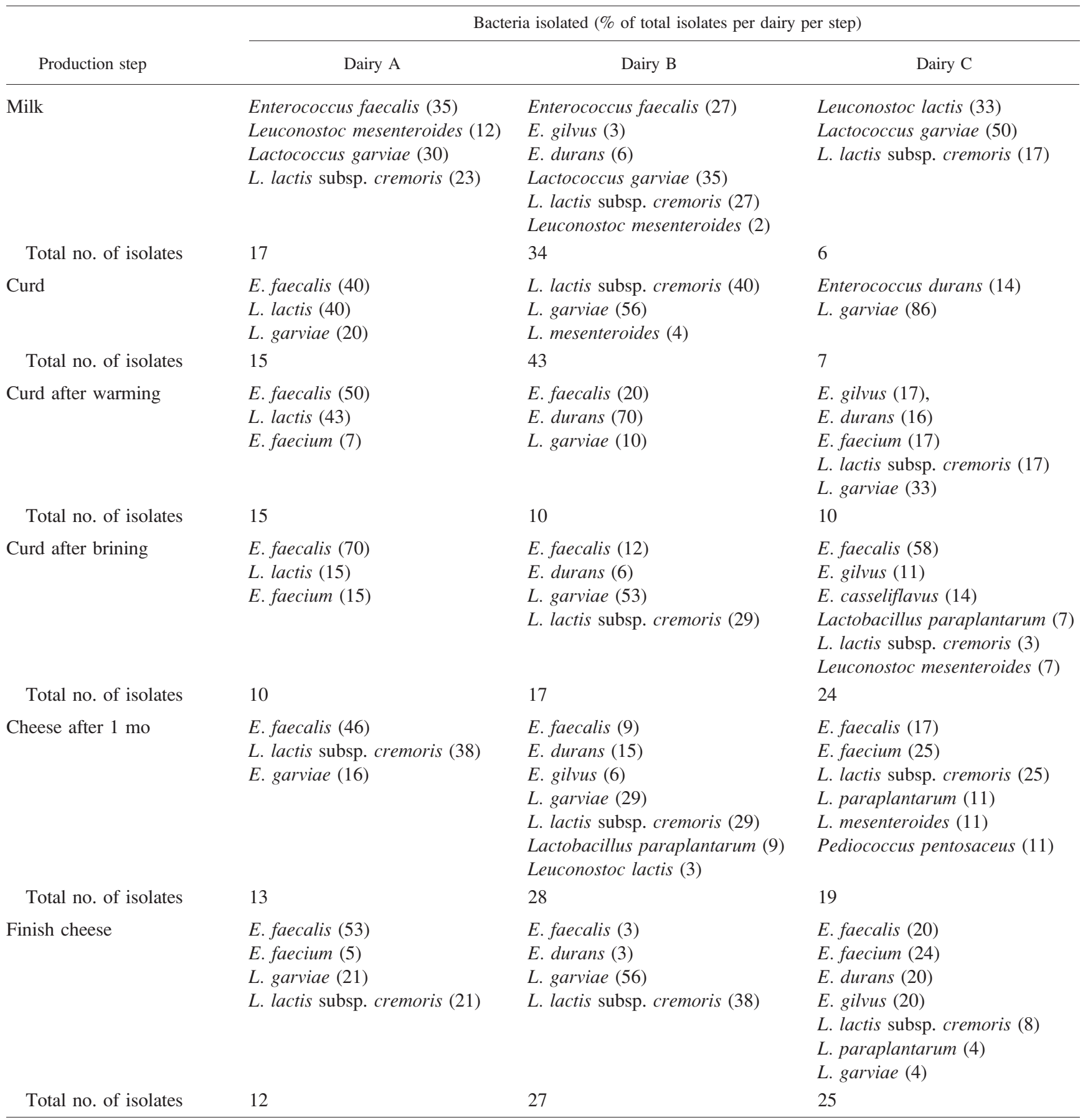

Enterococcus species are important during the cheesemanufacturing process, especially E. faecalis in the middle steps. Enterococci often are present in natural whey used as a starter culture in artisanal products. These bacteria have proteolytic and lipolytic activities that contribute to aroma development in the final cheese product during ripening $(6$, $12,14,16,23)$. Other strains produce bacteriocins active against undesirable microorganisms.

The LAB population found in the artisanal goat cheese in this study was characterized by growth of Enterococcus and Lactococcus species in the last phases of cheesemaking after brining. Lactobacillus and Leuconostoc are minority components of the LAB flora and were occasionally found in and associated with a specific dairy. The differences in the microbial populations we observed can be ascribed to different processing and environmental conditions that permit the selection of a specific ecosystem typical of each dairy.

\section{REFERENCES}

1. Beresford, T. P., N. A. Fitzsimons, N. L. Brennan, and T. M. Cogan. 2001. Recent advances in cheese microbiology. Int. Dairy J. 11:259274.

2. Berthier, F., and S. D. Ehrlich. 1998. Rapid species identification within two groups of closely related lactobacilli using PCR primers that target the $16 \mathrm{~S} / 23 \mathrm{~S}$ rRNA spacer region. FEMS Microbiol. Lett. 161:97-106. 
3. Bonetta, S., and E. Carraro. 2008. Microbiological characterization of Robiola di Roccaverano cheese using PCR-DGGE. Food Microbiol. 25:786-792.

4. Brandl, E., H. Asperger, F. Pfleger, and C. H. Iben. 1985. Zum vorkommen von D-Streptokokken in Käse. Arch. Lebensmittelhyg. $36: 18-22$.

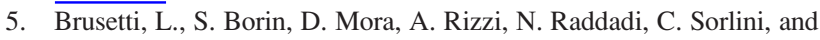
D. Daffonchio. 2006. Usefulness of length heterogeneity-PCR for monitoring lactic acid bacteria succession during maize ensiling. FEMS Microbiol. Ecol. 56:154-164.

6. Centeno, J. A., S. Menendez, M. Hermida, and J. L. Rodriguez-Otero. 1999. Effects of the addition of Enterococcus faecalis in Cebreiro cheese manufacture. Int. J. Food Microbiol. 48:97-111.

7. Centeno, J. A., S. Menendez, and J. L. Rodriguez-Otero. 1996. Main microflora present in natural starters in Cebreiro raw cow's milk cheese (northwest Spain). Int. J. Food Microbiol. 33:307-313.

8. Coppola, T. M., J. E. Parente, S. Dumontet, and A. Petrella. 1988. The microflora of natural whey cultures utilized as starters in manufacture of mozzarella cheese from water buffalo milk. Lait 68:295-310.

9. Dahllö, F. I., H. Baillie, and S. Kjelleberg. 2000. rpoB-based microbial community analysis avoids limitations inherent in 16S rRNA gene intraspecies heterogeneity. Appl. Environ. Microbiol. 66:3376-3380.

10. de Man, J. C., M. Rogosa, and M. E. Sharpe. 1960. A medium for the cultivation of lactobacilli. J. Appl. Bacteriol. 23:130-136.

11. Dolci, P., V. Alessandria, K. Rantsiou, L. Rolle, G. Zeppa, and L. Cocolin. 2008. Microbial dynamics of Castelmagno PDO, a traditional Italian cheese, with a focus on lactic acid bacteria ecology. Int. J. Food Microbiol. 122:302-311.

12. Fortina, M. G., G. Ricci, A. Acquati, G. Zeppa, A. Gandini, and P. L. Manachini. 2003. Genetic characterization of some lactic acid bacteria occurring in an artisanal protected denomination origin (PDO) Italian cheese, the Toma piemontese. Food Microbiol. 20:397-404.

13. Fox, P. F., P. L. H. McSweeney, and C. M. Lynch. 1998. Significance of non starter lactic acid bacteria in Cheddar cheese. Aust. J. Dairy Technol. 53:83-89.

14. Franzetti, L., M. Pompei, M. Scarpellini, and A. Galli. 2004. Phenotypic and genotypic characterization of Enterococcus spp. of different origins. Curr. Microbiol. 49:255-260.

15. Gatti, M., J. De Dea Lindner, A. De Lorentiis, B. Bottar, M. Santarelli, V. Bernini, and E. Neviani. 2008. Dynamics of whole and lysed bacterial cells during Parmigiano-Reggiano cheese production and ripening. Appl. Environ. Microbiol. 74:6161-6167.

16. Giraffa, G., D. Carminati, and E. Neviani. 1997. Enterococci isolated from dairy products: a review of risks and potential technological use. J. Food Prot. 60:732-738.
17. Haenlein, G. F. W. 2004. Goat milk in human nutrition. Small Ruminant Res. 51(2):155-163.

18. Huey, B., and J. Hall. 1989. Hypervariable DNA fingerprinting in Escherichia coli. Minisatellite probe from bacteriophage M13. J. Bacteriol. 171:2528-2532.

19. Jany, J., and G. Barbier. 2008. Culture-independent methods for identifying microbial communities in cheese. Food Microbiol. 25: 839-848.

20. Lazzi, C., L. Rossetti, M. Zago, E. Neviani, and G. Giraffa. 2003. Evaluation of bacterial communities belonging to natural whey starters for Grana Padano cheese by LH-PCR. J. Appl. Microbiol. 96: 481-490.

21. Mannu, L., G. Riu, R. Comunian, M. C. Frozzi, and M. F. Scintu. 2002. A preliminary study of lactic acid bacteria in whey starter culture and industrial Pecorino Sardo ewes milk cheese: PCR identification and evolution during ripening. Int. Dairy J. 12:17-26.

22. Mora, D., M. G. Fortina, C. Parini, D. Daffonchio, and P. L. Manachini. 2000. Genomic subpopulations within the species Pediococcus acidilactici detected by multilocus typing analysis: relationship between pediocin $\mathrm{AcH} / \mathrm{PA}-1$ producing and nonproducing strains. Microbiology 146:2027-2038.

23. Mucchetti, G., and E. Neviani. 2006. Microbiologia e tecnologia lattiero casearia. Qualità e sicurezza. Tecniche Nuove, Milan.

24. Nikolic, M., A. Terzic-Vidjevic, B. Jovcic, J. Bogovic, N. Golic, and L. Topisirovic. 2008 Characterization of lactic acid bacteria isolated from Bukuljac, a homemade goat's milk cheese. Int. J. Food Microbiol. 122:162-170.

25. Ogier, J. C., V. Lafarge, and V. Girard. 2004. Molecular fingerprinting of dairy microbial ecosystems by use of temporal temperature and denaturing gradient gel electrophoresis. Appl. Environ. Microbiol. 70:5628-5643.

26. Psoni, L., C. Kotzamanidis, and M. Yiangou. 2007. Genotypic and phenotypic diversity of Lactococcus lactis isolated from Batzos, a Greek PDO raw goat milk cheese. Int. J. Food Microbiol. 114:211220.

27. Sánchez, I., S. Seseña, J. Poveda, L. Cabezas, and L. Palop. 2005. Phenotypic and genotypic characterization of lactobacilli isolated from Spanish goat cheeses. Int. J. Food Microbiol. 102:355-362.

28. Terzaghi, B. E., and W. E. Sandine. 1975. Improved medium for lactic streptococci and their bacteriophages. Appl. Microbiol. 29:807813.

29. Terzic-Vidjevic, A., M. Vukasinovic, K. Veljovic, M. Opstojic, and L. Topisirovic. 2007. Characterization of microflora in homemade semi-hard white Zlatar cheese. Int. J. Food Microbiol. 114:36-42. 